\title{
Wind tunnel study of natural ventilation of building integrated photovoltaics double skin façade
}

\author{
Sebastian Valeriu Hudișteanu ${ }^{1}$, Cătălin George Popovici ${ }^{1}$, and Nelu-Cristian Cherecheș ${ }^{1, *}$ \\ 1،Gheorghe Asachi” Technical University of Iaşi, Faculty of Civil Engineering and Building Services, Romania
}

\begin{abstract}
The paper presents a wind tunnel experimental analysis of a small-scale building model (1:30). The objective of the study is to determine the wind influence on the ventilation of a double skin façade channel (DSF) and the cooling effect over integrated photovoltaic panels. The tests were achieved by conceiving and implementation of an experimental program using a wind tunnel with atmospheric boundary layer. The effect of the wind over the ventilation of the horizontal channels of double skin façades is evaluated for different incident velocities. The results are generalized for the average steady state values of the velocities analysed. The experimental results put in evidence the correlation between the reference wind velocity and the dynamics of the air movement inside the double skin façade. These values are used to determine the convective heat transfer and the cooling effect of the air streams inside the channel upon the integrated photovoltaic panels. The decrease of the photovoltaic panels temperature determines a raise of $11 \%$ in efficiency and power generated.
\end{abstract}

\section{Introduction}

The complex effect of the wind over buildings is most often studied using wind tunnel simulations. The analysis is focused on the dynamic loads on the buildings facades [1, 2], snow accumulation on roofs [3] or natural ventilation of the indoor environment [4]. When buildings are exposes to the wind, some aerodynamic effects such as the bar, Venturi, stack, corner, slipstream or pyramid effect are generated [5].

The air velocity and direction has a random character, which represents the most important problem for studying its action on the buildings. Typically, for designing the wind effect, the mean values for velocity and direction are used. The probabilistic theories are used to determine the effects of the fluctuations, by knowing the statistical distributions specific of the wind velocities and pressures. The standard meteorological measurements are made using anemometers. The continuous and discontinuous recorded values are used for determining the 10 minutes average values, that is used to obtain the characteristic basic wind velocity [5]. Usually, the basic wind velocity, $v_{b}$, includes both the direction and season effects and it is measured at $10 \mathrm{~m}$ height, with $2 \%$ probability of annual exceeding the mean [5].

The mean wind velocity, $v_{m}(z)$, is also based on the $v_{b}$ value, but varies with the height from the ground, $z$, with the roughness of the terrain and orographic particularities of the site [16].

The basic wind pressure, $\mathrm{p}_{b}$, can be determined using the basic wind velocity, $v_{b}$ :

$$
p_{b}=\frac{\rho \cdot v_{b}^{2}}{2}
$$

where, $\quad \rho$ - air density $\left[\mathrm{kg} / \mathrm{m}^{3}\right]$.

Usually, the mean wind speed maintains its dynamic and random character, while the spatial fluctuations of the instantaneous velocity have also an important role. The instant velocity at the height $z$ above the ground has two components:

$$
v(z)=v_{\text {med }}(z)+v^{\prime}(z)
$$

where, $v_{\text {med }}(z)$ - mean velocity on time interval $\tau[\mathrm{m} / \mathrm{s}]$;

$$
v^{\prime}(z) \text { - fluctuating velocity }[\mathrm{m} / \mathrm{s}] \text {. }
$$

The mean value is a characteristic of the wind profile, while the fluctuating component is used for measuring the turbulence intensity and quantifies the maximum and minimum velocities.

The peak velocity pressure, $q_{p}(z)$, becomes relevant for designing the wind action, because it includes the effects of the random wind speed and pressure fluctuations. The peak pressure is obtained by using an exposure factor, which increases the basic velocity pressure, $p_{b}$, about $3,4 \ldots 4$ times, proportional to the height above the ground and the turbulence intensity.

The wind velocity and direction have a spatial variation in horizontal and vertical planes. The urban areas are characterized by lower wind velocities, but increased turbulence intensities, while the open fields are characterized by higher wind velocities and lower turbulence intensity - Fig. 1 [5].

\section{* Corresponding author: chereches@tuiasi.ro}




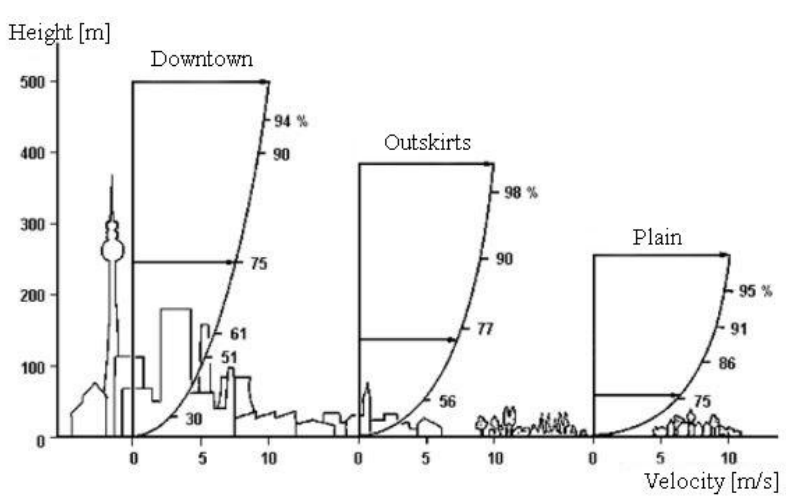

Fig. 1. Wind velocity in urban areas.

The wind effect on the ventilation of double skin façades is studied in literature $[6-10,18]$. Recent studies are also focused on the building integrated photovoltaics system $[1,11-14]$. These studies provide both qualitative and quantitative data concerning the influence of the wind on the natural circulation of the air inside double skin facades and cooling effect of airstreams [14].

The action of the wind causes a dynamic pressure, which is increasing with the height [5], and has a favourable effect for the ventilation of double skin facades. When the wind velocity is $10 \mathrm{~m} / \mathrm{s}$ or higher, the flow becomes neutrally stable. Most often, the wind action upon the façades of the building determines a series of local pressures and suctions.

It is recommended to use simulations in wind tunnels with turbulent boundary layer in order to determine the wind action on the buildings [16]. These tests are distinguished by the similarity requirement for the model and prototype [16]. The main target of the studies is to identify the similarity model and the criteria necessary for simulation and also in detecting the similarity criteria that may be passed by, due to their irrelevance [5].

Usually, the analysis made in wind engineering, showed that the inertial forces prevail, and the flow is a turbulent one, at very high Reynolds numbers $(R e)$. Also, for objects with sharp edges, the similarity is ensured by self-modelling, being insensitive to the $R e$ numbers [5]. Some studies regarding the simulations in wind tunnel showed that a self-modelling condition is accomplished when $R e$ numbers reach values of $(0.5 \ldots 1.2) \cdot 10^{5}$ [5]. The self-modelling of the airflow over the bluff bodies simplifies physical models and avoid the inconveniences in satisfying the similarity requirements [15].

The current analysis is focussed in determining the wind effect over the ventilation of the vertical channels of double skin façades. The results for velocities are processed as average steady state values of 4 series of measurement of 30 seconds, resulting a total time of 2 minutes for each case. The frequency of measurement was set to 1000 values/second. The study was achieved by conceiving and implementing an experimental program in the atmospheric boundary layer wind tunnel.

\section{Experimental setup}

A reduced scale model (1:30) of a ventilated double skin façade is experimentally tested in a wind tunnel. A real building is a 3 stores building, $13.5 \mathrm{~m}$ height and $12 \mathrm{~m}$ width is modelled. The outer layer of the double skin façade system is realized from photovoltaic (PV) panels. The purpose of the study consists in determining the cooling effect of the air circulation when wind is incident on the façade of the building [5].

During the study, it is obtained with acceptable probability the air speed inside double skin façade, near the PV panels, during hot season. Also, a series of correlations between reference velocity and the velocities inside the channel are established.

The experimental measurements consist in obtaining the reference wind velocity, dynamic, static and total pressures, inside the channel of the double skin façade and in the external environment. The scale of the model, $1: 30$, was restricted by the dimensions of the transversal section of the wind tunnel, with $1.4 \mathrm{~m}$ height and $1.4 \mathrm{~m}$ width. Therefore, from the necessity of avoiding blockage of the airflow in the cross section, the transversal projection of the building was reduced to a maximum of $10 \%$ of the wind tunnel's one, resulting an area of $0.196 \mathrm{~m}^{2}$. In these conditions, the building model has been constrained to the transversal dimensions of $0.40 \mathrm{~m} \times 0.475 \mathrm{~m}$, with an effective area of $0.19 \mathrm{~m}^{2}$. The width of the channel of the ventilated façade is $0.01 \mathrm{~m}$ for the model, equivalent to a $0.3 \mathrm{~m}$ on the real building. The building model is made of transparent plastic material (Plexiglass), and it has the components and dimensions presented in Fig. 2.

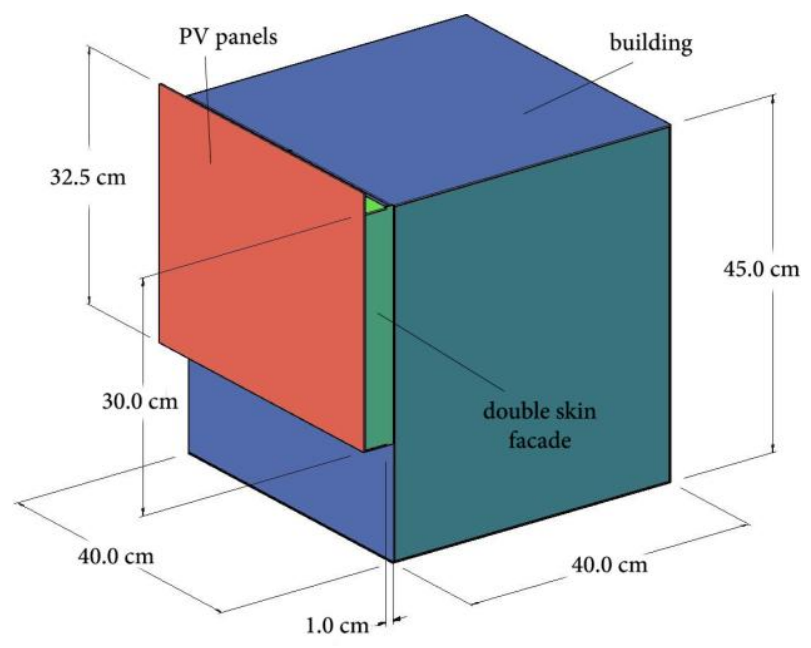

Fig. 2. Dimensions and components of the model for the building with double skin façade.

The model represents a building equipped with ventilated double skin façade system. The external glazing is considered to be replaced with photovoltaic panels, in order to achieve a building integrated photovoltaic system (BIPV). The present configuration of the double skin façade consists in three horizontal compartments on the full height and width of one façade and the air circulation due to wind action is supposed to cool the PV panels. The wind tunnel testing program is based on the assumption that for the full-scale buildings the air circulates horizontally, determined by the temperature gradient and wind action, avoiding the vertical overheating inside the channel. The main 
components and geometrical details of this configuration are displayed in Table 1 and Fig. 3 - Fig. 4.

Table 1. Double skin façade channel.

\begin{tabular}{|c|}
\hline-3 inlet sections $\left(S_{i n}\right)$ \\
\hline-3 outlet sections $\left(S_{e v}\right)$ \\
\hline - total area of inlet section: $S_{i n}=3 \times(10 \times 1)=30 \mathrm{~cm}^{2}$ \\
\hline$-S_{e v}=S_{i n}=30 \mathrm{~cm}^{2}$ \\
\hline
\end{tabular}

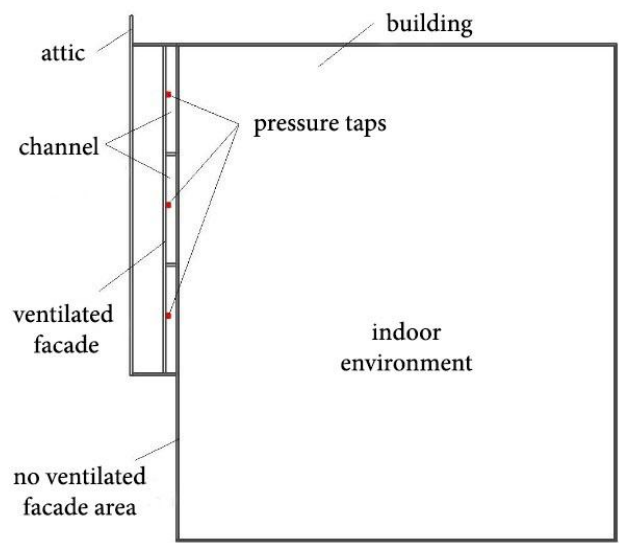

Fig. 3. Cross section through building model.

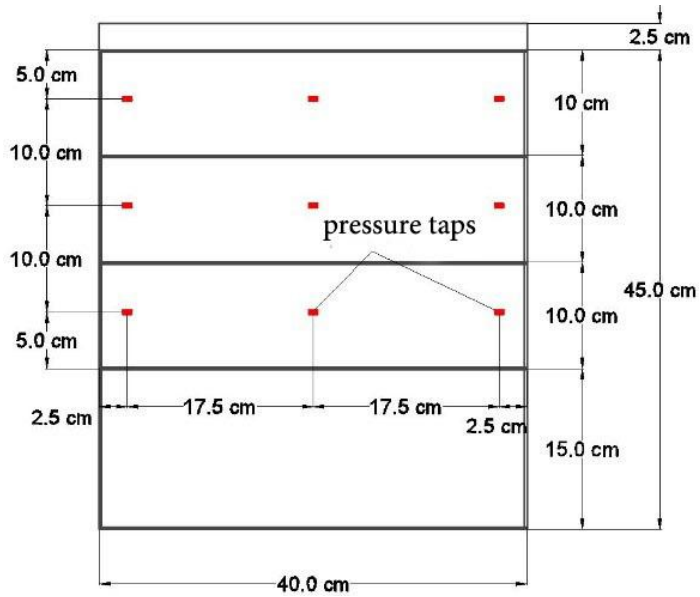

Fig. 3. Front view of the building model.

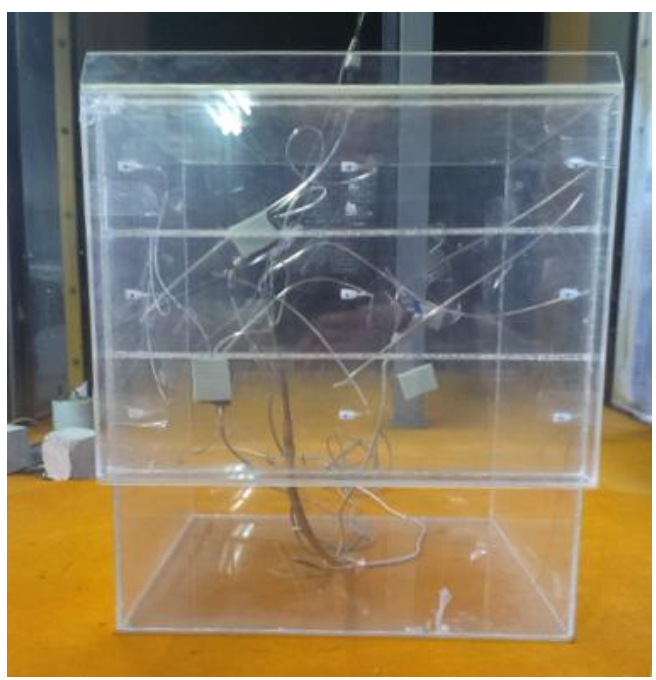

Fig. 4. Front view of the building model inside the wind tunnel - position of the pressure taps.
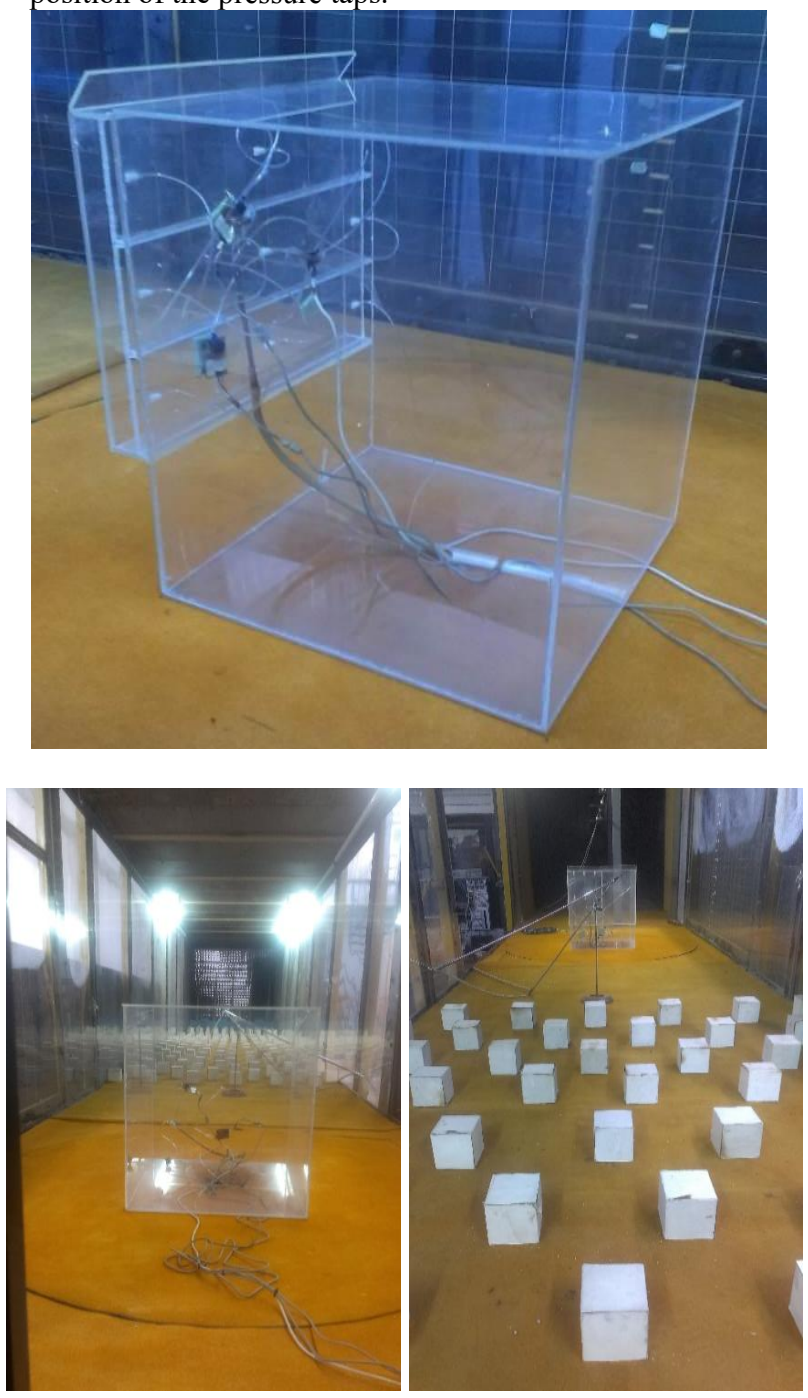

Fig. 5. Overview of the positioning of the model inside the wind tunnel and the rough elements for creating turbulence.

The wind tunnel is $10 \mathrm{~m}$ length and has rough elements that are creating the turbulent boundary layer, Fig. 5. The building model is placed at $6 \mathrm{~m}$ towards the turbulence grid of the tunnel.

The measurements of dynamic pressures and air speed are realized by a Pitot tube and a hot wire anemometer. Both measuring probes are placed at a $0.33 \mathrm{~m}$ height in the front of the building, equivalent to $10 \mathrm{~m}$ on the real scale. This point is named during the study, the reference velocity point, $v_{\text {ref }}$.

The direction of the wind in the reference point is normal to the double skin façade of the building model, as shown in Fig. 6. During the experimental study, the wind effect was tested for different reference velocities of 1,2 , 3,4 and $5 \mathrm{~m} / \mathrm{s}$. 


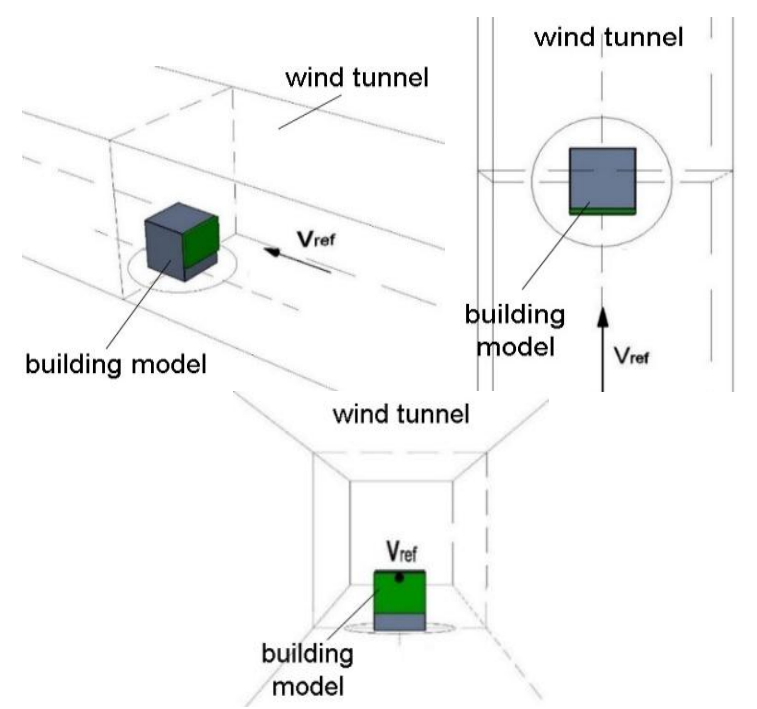

Fig. 6. Direction of the reference wind.

\section{Results}

The following results are based on the assumption that in case of this type of the building model, with sharp edges, it can be approximated that by assuring the geometric similarity, then the dynamic similarity is also performed. This hypothesis is available if the Reynolds numbers are superior to the turbulent flow limit.

In order to obtain a general view of the phenomenon, taking into account the self-modelling, the measured values are represented as dimensionless velocity coefficients:

$$
c_{v}=\frac{v_{m}}{v_{r e f}}
$$

where, $v_{m}$ - average velocity of the air inside the channel of the ventilated façade $[\mathrm{m} / \mathrm{s}]$; point $[\mathrm{m} / \mathrm{s}]$.

$v_{\text {ref }}$ - average velocity of the air at the reference

These coefficients quantify the wind effect over the natural circulation of the air through the double skin façade channel. For reference velocities higher than 3 $\mathrm{m} / \mathrm{s}$, the self-modelling of the process is noticed and the coefficient determined using Eq. 3 tend to become constant, Fig 7. The self-modelling conditions were achieved and the results for the other velocities were neglected. Therefore, the $c_{v}$ coefficients are the mean of these three velocities. Their values are very approximate, with differences compared to the mean of less than $30 \%$.

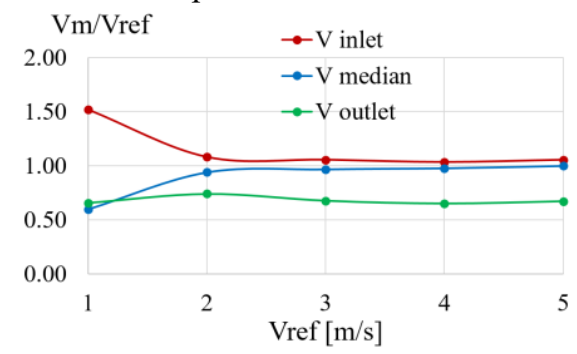

Fig. 7. Evolution of the $c_{v}$ coefficient depending on the reference velocity $v_{\text {ref }}$.
The Re numbers to which the experiment was accomplished are synthesized in Table 2. It was noted that the values determined for reference velocities above $3 \mathrm{~m} / \mathrm{s}$ confirm the previous assumption that the selfmodelling is achieved for the studied model.

Table 2. Reynolds number depending on the reference velocity.

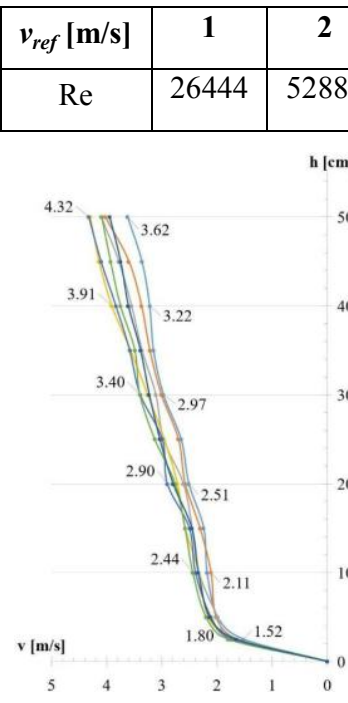

a)

\begin{tabular}{|c|c|c|}
\hline $\mathbf{3}$ & $\mathbf{4}$ & $\mathbf{5}$ \\
\hline 79333 & 105778 & 132222 \\
\hline
\end{tabular}

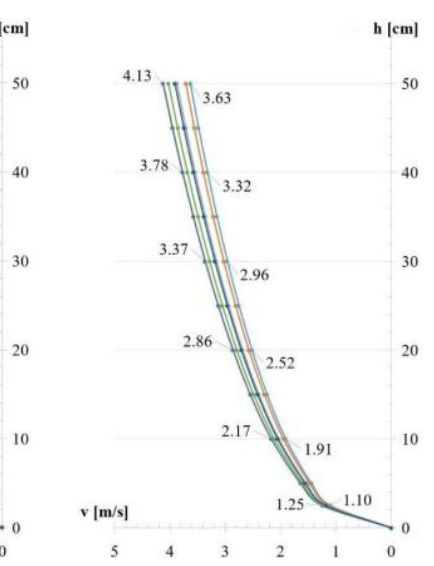

Fig. 8. Comparison between vertical distribution of the reference velocity of experimental data (a) and exponential distribution law (b) at $v_{\text {ref }}=5 \mathrm{~m} / \mathrm{s}$.

The experimental results showed that the distribution of measured velocities is very close to the theoretical law, Fig. 8, with small differences for low level, at heights of maximum $5 \mathrm{~cm}$ from the horizontal plane. The match ratio of these distributions is presented in Table 3, for the reference velocity of $5 \mathrm{~m} / \mathrm{s}$. From $10 \mathrm{~cm}$ height above, the match is between 0.94 and 1.19 for the three reference velocities. This correspondence between experimental values and theoretical ones is very important and validates the results of the study.

Table 3. Match ration between the distribution of measured velocities and theoretical exponential law $\left(v_{\text {ref }}=5 \mathrm{~m} / \mathrm{s}\right)$.

\begin{tabular}{|c|c|c|c|c|c|c|c|}
\hline $\begin{array}{c}\boldsymbol{d}[\mathbf{c m}] \\
\boldsymbol{h}[\mathbf{c m}]\end{array}$ & $\mathbf{3 0}$ & $\mathbf{2 0}$ & $\mathbf{1 0}$ & $\mathbf{0}$ & $\mathbf{1 0}$ & $\mathbf{2 0}$ & $\mathbf{3 0}$ \\
\hline 2,5 & 1,39 & 1,45 & 1,50 & 1,37 & 1,40 & 1,48 & 1,41 \\
\hline 5 & 1,38 & 1,37 & 1,29 & 1,32 & 1,28 & 1,37 & 1,37 \\
\hline 10 & 1,14 & 1,08 & 1,14 & 1,08 & 1,10 & 1,15 & 1,14 \\
\hline 15 & 1,00 & 1,01 & 1,02 & 1,01 & 0,98 & 1,04 & 1,02 \\
\hline 20 & 1,00 & 1,00 & 0,97 & 0,95 & 1,01 & 0,99 & 1,03 \\
\hline 25 & 0,96 & 0,96 & 1,01 & 0,95 & 0,96 & 1,03 & 1,03 \\
\hline 30 & 1,00 & 0,99 & 0,98 & 0,97 & 1,01 & 1,04 & 1,01 \\
\hline 35 & $\mathbf{1 , 0 0}$ & $\mathbf{1 , 0 0}$ & $\mathbf{1 , 0 0}$ & $\mathbf{1 , 0 0}$ & $\mathbf{1 , 0 0}$ & $\mathbf{1 , 0 0}$ & $\mathbf{1 , 0 0}$ \\
\hline 40 & 0,97 & 0,99 & 1,00 & 1,04 & 1,01 & 1,02 & 1,01 \\
\hline 45 & 0,96 & 1,01 & 1,02 & 1,05 & 1,04 & 1,02 & 1,00 \\
\hline 50 & 1,00 & 1,09 & 1,06 & 1,04 & 1,05 & 1,02 & 1,01 \\
\hline
\end{tabular}


where, $d$ - horizontal measurement (distance from the axis of the wind tunnel) $[\mathrm{cm}]$;

$h$ - vertical measurement points (height above the floor of the wind tunnel) [cm].

The theoretical exponential law of vertical distribution of the wind velocities is:

$$
v_{z}=v_{g} \cdot\left(\frac{z}{z_{g}}\right)^{\alpha}=v_{10} \cdot\left(\frac{z}{z_{10}}\right)^{\alpha}
$$

where, $v_{z}-$ wind velocity at height $\mathrm{z}[\mathrm{m} / \mathrm{s}]$;

$v_{g}$ - gradient velocity $[\mathrm{m} / \mathrm{s}]\left(v_{g}=v_{10}\right)$;

$z$ - calculation height $[\mathrm{m}]$;

$z_{g}-$ gradient height $[\mathrm{m}]\left(z_{g}=z_{10}=10 \mathrm{~m}\right) ;$

$\alpha$ - coefficient of terrain.

The averaged values for $c_{v}$ coefficients are represented in Fig. 9, in different measuring points.

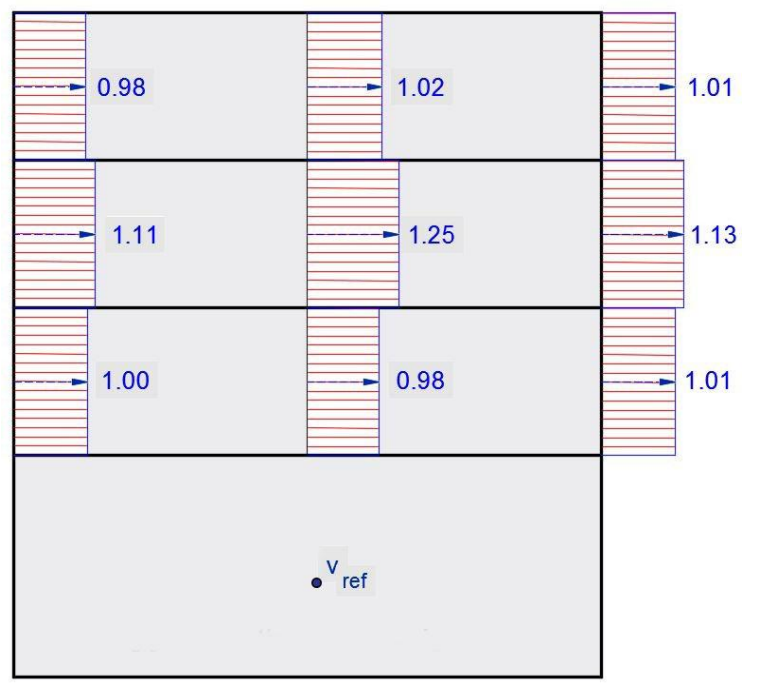

Fig. 9. $c_{v}$ coefficients determined in measuring points.

The results regarding the $c_{v}$ coefficients of the velocities inside the channels conducted to the analysis of the convective heat transfer coefficients obtained in the case of a real building, with the same geometrical characteristic as the modelled one.

Based on the $c_{v}$ values, the convective heat transfer coefficients, $h_{c}$, inside double skin façade channel, near PV panels were calculated.

Taking into account the annual average velocities in real conditions, the convective heat transfer coefficients were calculated for reference velocities between $0,5 \mathrm{~m} / \mathrm{s}$ and 3 $\mathrm{m} / \mathrm{s}$. Therefore, for this configuration of the double skin façade, the $h_{c}$ coefficients reach the values according to Table 4.

Table. 4. Heat transfer coefficients, $h_{c}$, inside the double skin façade channel for $c_{v}=0,98 \ldots 1,25$.

\begin{tabular}{|c|c|c|c|}
\hline \multirow{2}{*}{$\begin{array}{c}v_{\text {ref }} \\
{[\mathrm{m} / \mathrm{s}]}\end{array}$} & \multicolumn{3}{|c|}{$h_{c}\left[\mathrm{~W} / \mathrm{m}^{2} \cdot \mathrm{K}\right]$} \\
\cline { 2 - 4 } & Inferior & Median & Superior \\
\hline 0,50 & 2,30 & $\mathbf{2 , 8 0}$ & 2,38 \\
\hline 1,00 & 4,01 & $\mathbf{4 , 8 7}$ & 4,14 \\
\hline 1,50 & 5,54 & $\mathbf{6 , 7 3}$ & 5,72 \\
\hline 2,00 & 6,98 & $\mathbf{8 , 4 8}$ & 7,20 \\
\hline 2,50 & 8,34 & $\mathbf{1 0 , 1 3}$ & 8,61 \\
\hline 3,00 & 9,65 & $\mathbf{1 1 , 7 2}$ & 9,96 \\
\hline
\end{tabular}

For the usual air velocities of $0,5 \ldots 3,0 \mathrm{~m} / \mathrm{s}$, the heat transfer coefficient inside the double skin façade channel achieve maximum values of about $2,8 \ldots 11,72 \mathrm{~W} / \mathrm{m}^{2} \cdot \mathrm{K}$ in the median channel.

The analysis of the cooling impact over the integrated photovoltaic panels is based on the temperature effect over their efficiency [17]. A typical efficiency of the photovoltaic effect of $16 \%$ is considered, for solar radiation of $1000 \mathrm{~W} / \mathrm{m}^{2}$. Given that in the present study the photovoltaics integration is realized on vertical surface (exterior layer of the double skin façade), a 500 $\mathrm{W} / \mathrm{m}^{2}$ nominal solar radiation can be considered [17]. In order to simplify the interpretation of the results, all data are related to a $1 \mathrm{~m}^{2}$ monocristaline PV panel.

The power produced by the PV panel, at $500 \mathrm{~W} / \mathrm{m}^{2}$ and $25{ }^{\circ} \mathrm{C}$ is about $73.4 \mathrm{~W} / \mathrm{m}^{2}$. The influence of cooling is calculated by taking into consideration an overall effect of the temperature over the efficiency of $-0.45 \% / \mathrm{C}$ [17]. The solar radiation effect used in calculation has a value of $1,66 \% / 100 \mathrm{~W} / \mathrm{m}^{2}$ at $500 \mathrm{~W} / \mathrm{m}^{2}$.

Therefore, for the base case, when the PV panel is integrated in the façade without ventilation, an operating temperature of $75^{\circ} \mathrm{C}$ can be achieved. This temperature reduces the maximum power generated by PV panel to $77.5 \%$ of the nominal one. In Table 5 is presented the effect of the cooling the PV panel for different reference velocities.

Table 5. Effect of cooling over the PV panel's efficiency

\begin{tabular}{|c|c|c|c|c|c|}
\hline Case & $\mathrm{t}\left[{ }^{\circ} \mathrm{C}\right]$ & $\begin{array}{c}{[\%]} \\
\text { of } \mathrm{P}_{\mathrm{N}}\end{array}$ & $\begin{array}{c}\eta \\
{[\%]}\end{array}$ & $\begin{array}{c}\mathrm{P}_{\text {gen }} \\
{[\mathrm{W}]}\end{array}$ & $\begin{array}{c}\text { Increase } \\
\text { over base } \\
\text { case [\%] }\end{array}$ \\
\hline base case & 75 & 77.5 & 11.37 & 14.22 & - \\
\hline $\mathrm{v}=0.5 \mathrm{~m} / \mathrm{s}$ & 70.4 & 79.7 & 11.67 & 14.62 & 2.81 \\
\hline $\mathrm{v}=1,0 \mathrm{~m} / \mathrm{s}$ & 62.6 & 83.4 & 12.19 & 15.30 & 7.59 \\
\hline $\mathrm{v}=1.5 \mathrm{~m} / \mathrm{s}$ & 55.5 & 86.3 & 12.66 & 15.83 & 11.32 \\
\hline
\end{tabular}

\section{Conclusions}

The experimental results have revealed the effect of the wind over the air circulation and velocities inside double skin façade channel in the near vicinity of the photovoltaic panels. The air flow inside the double skin façade is predominantly horizontal, which represents an important aspect in order to avoid the vertical overheating and extreme thermal draft effect during summer.

The results, quantified as $c_{v}$ coefficients, showed that the average velocity of the air near the exterior glazing of the double skin façade is dependent on the reference velocity, $v_{r e f}$, and has the same order of magnitude. The averaged values of the coefficients, $c_{v}$, in the median area of the façade, reach values between $1.11 \ldots 1.25$. For the inlet and outlet sections, these coefficients are laying between $0.59 \ldots 0.91$.

The double skin façade system is very suitable for building integrated photovoltaic solutions. Therefore, a combination of aesthetics and efficiency is achieved. The cooling effect of natural ventilation of channel by wind action revealed a possible increase of the generated 
electric power between $2.81 \ldots 11.32 \%$ compared to the base case.

\section{References}

1. Vasan N., Stathopoulos T., Wind Tunnel Assessment of the Wind Velocity Distribution on Vertical Façades, Proceedings of eSim, 2012, pp. 61-74.

2. Quirouette R., Arch B., La pression d'air et l'envelope du batiment, Ontario Association of Architects, 2004.

3. Axinte E., Teleman E. C., Băetu G., Pescaru R. A., Silion R., Studies for preventing the impact of climate changes upon built environment, The Bulletin of the Polytechnic Institute of Jassy, CA Section, Tome: LXI (LXV), 2015, pp. 61-74.

4. Flamand O., Action du vent sur les ouvrages Effets dynamiques, Universite de Nantes.

5. Axinte E., Pescaru R. A., Studiul acțiunii vântului în tunel aerodinamic, Editura Cermi, Iași, Romania, 2000.

6. Loua W., Huang M., Zhang M., Lin N., Experimental and zonal modeling for wind pressures on double-skin facades of a tall building, Energy and Buildings, Vol. 54, 2012, pp.179-191.

7. Kawai H., Nishimura H., Suzuki M., Oura Y., Field Measurement of Wind Pressure on a Double Skin with a Ventilator, EACWE 5 Florence, 12 pages, 2009.

8. Silva F.M., Gomes M.G., Rodrigues A.M., Measuring and estimating airflow in naturally ventilated double skin facades, Building and Environment, Vol. 87, 2015, pp. 292-301.

9. Tominaga Y., Blocken B., Wind tunnel experiments on cross-ventilation flow of a generic building with contaminant dispersion in unsheltered and sheltered conditions, Building and Environment, Vol. 92, 2015, pp. 452-461.

10. Barbosa S., Ip K., Perspectives of double skin façades for naturally ventilated buildings: A review, Renewable and Sustainable Energy Reviews, Vol. 40, 2014, pp. 1019-1029.

11. Agathokleous R.A., Kalogirou S.A., Double skin facades (DSF) and building integrated photovoltaics (BIPV): A review of configurations and heat transfer characteristics, Renewable Energy Vol. 89, 2016, pp. 743-756.

12. Sacht H., Bragança L., Almeida M., Caram R., Different module placements in a modular façade system for natural ventilation, Economics and Finance, Vol. 21, 2015, pp. 366-373.

13. Gaillard L., Ruedin, G. Giroux, Plantevit M., Kaytoue M., Saadon S., Ménézo C., Boulicaut J.-F., Data-driven performance evaluation of ventilated photovoltaic double-skin facades in the built environment, Energy Procedia, Vol. 78, 2015, pp 447-452.

14. Hudișteanu S.V., Popovici C.G., Mateescu T.D., Cherecheș N.-C., Efficiency analysis of BIPV systems for different locations in Romania, Energy Procedia, Vol. 112, 2017, pp. $404-411$.

15. Neff D.E., Meroney N.R., Reynolds number independence of the wind tunnel simulation of transport and dispersion about buildings, Colorado State University, 20 pages, 1996.

16. Sacht H., Bragança L., Almeida M., Caram R., Study of natural ventilation in wind tunnels and influence of the position of ventilation modules and types of grids on a modular façade system, Energy Procedia 96 (2016) 953 - 964.

17. Popovici C.-G, Hudişteanu, S. V., Mateescu T. D., Cherecheş N.-C., (2016), Efficiency improvement of PV panels by using air cooled heat sinks, Energy Procedia, 85, 425-432.

18. Popovici C.-G., Cirlan V.V., Mateescu T.D., Chereches N.-C., Hudisteanu S.V., Influence of various angles of the venetian blind on the efficiency of a double skin façade, Energy Procedia 85 (2016) 416 - 424. 